\title{
Rapid Suppression of Inhibitory Synaptic Transmission by Retinoic Acid
}

\author{
Federica Sarti, ${ }^{1,2}$ Zhenjie Zhang, ${ }^{1}$ Jessica Schroeder, ${ }^{1}$ and Lu Chen ${ }^{1}$ \\ ${ }^{1}$ Stanford Institute of Neuro-Innovation and Translational Neuroscience, and Department of Psychiatry and Behavioral Sciences, Stanford University \\ School of Medicine, Stanford, California 94305, and ${ }^{2}$ University of California, Department of Molecular and Cell Biology, Berkeley, California 94720
}

In brain, properly balanced synaptic excitation and inhibition is critically important for network stability and efficient information processing. Here, we show that retinoic acid (RA), a synaptic signaling molecule whose synthesis is activated by reduced neural activity, induces rapid internalization of synaptic $\mathrm{GABA}_{\mathrm{A}}$ receptors in mouse hippocampal neurons, leading to significant reduction of inhibitory synaptic transmission. Similar to its action at excitatory synapses, action of RA at inhibitory synapses requires protein translation and is mediated by a nontranscriptional function of the RA-receptor RAR $\alpha$. Different from RA action at excitatory synapses, however, RA at inhibitory synapses causes a loss instead of the gain of a synaptic protein (i.e., $G_{A B A} A_{A}$ ). Moreover, the removal of GABA $\mathrm{Rs}_{\mathrm{A}}$ from the synapses and the reduction of synaptic inhibition do not require the execution of RA's action at excitatory synapses (i.e., downscaling of synaptic inhibition is intact when upscaling of synaptic excitation is blocked). Thus, the action of RA at inhibitory and excitatory synapses diverges significantly after the step of RAR $\alpha$-mediated protein synthesis, and the regulations of GABA $\mathrm{R}$ and AMPAR trafficking are independent processes. When both excitatory and inhibitory synapses are examined together in the same neuron, the synaptic excitation/ inhibition ratio is significantly enhanced by RA. Importantly, RA-mediated downscaling of synaptic inhibition is completely absent in Fmrl knock-out neurons. Thus, RA acts as a central organizer for coordinated homeostatic plasticity in both excitatory and inhibitory synapses, and impairment of this overall process alters the excitatory/inhibitory balance of a circuit and likely represents a major feature of fragile X-syndrome.

\section{Introduction}

Optimal information processing requires that changes in the inputs of a neural network efficiently and faithfully translate into changes in their outputs, an ability that demands both network stability and appropriately balanced synaptic connectivity. In this regard, much attention has focused on excitatory synaptic transmission, as it is the direct driving force for generating postsynaptic action potentials and for propagation of information. However, inhibitory synaptic transmission is critically involved in gating, sculpting, and tuning the output generated by excitatory inputs and, in some cases, even in instructing excitatory synaptic plasticity (Fagiolini et al., 2004; Haider et al., 2006; Sibilla and Ballerini, 2009; Levy and Reyes, 2011). It is therefore likely that synaptic inhibition also undergoes plastic changes in response to altered inputs (i.e., reduced or blocked synaptic excitation), thus shifting the excitation/ inhibition ratio and achieving balanced synaptic excitation and inhibition.

\footnotetext{
Received April 23, 2013; revised May 17, 2013; accepted June 4, 2013.

Author contributions: F.S. and L.C. designed research; F.S., Z.Z., J.S., and L.C. performed research; F.S., Z.Z., and L.C. contributed unpublished reagents/analytic tools; F.S., Z.Z., and L.C. analyzed data; F.S. and L.C. wrote the paper.

This work was supported by National Institute of Mental Health Grants 1P50MH86403 and 1R01MH091193 to L.C.

The authors declare no competing financial interests.

Correspondence should be addressed to Dr. Lu Chen, Stanford University, Lorry I. Lokey Stem Cell Research Building, 265 Campus Drive, Room G1034B, Stanford, CA 94305-5453. E-mail: luchen1@stanford.edu.

DOI:10.1523/JNEUROSCI.1710-13.2013

Copyright $\odot 2013$ the authors $\quad 0270-6474 / 13 / 3311440-11 \$ 15.00 / 0$
}

The efficient modulation of excitation and inhibition underlies the homeostatic adaptations observed in different systems, such as the developing visual cortex (Komatsu, 1994; Hensch et al., 1998; Morales et al., 2002; Maffei et al., 2004; Hensch and Fagiolini, 2005), the auditory cortex (Kotak et al., 2005; Sun et al., 2010; Yang et al., 2011), and the barrel cortex (Higley and Contreras, 2006; House et al., 2011). In addition, numerous pathological conditions, such as autism, schizophrenia, epilepsy, and intellectual disability, may arise from the inability of neural networks to homeostatically adjust to external inputs (Ramocki and Zoghbi, 2008). In particular, in fmr1 KO mice, a mouse model of Fragile-X syndrome, absence of homeostatic adjustment of synaptic excitation (Soden and Chen, 2010), and evidence for an altered excitation/inhibition balance (Gibson et al., 2008) have both been demonstrated, emphasizing the primary role of the dynamic regulation of the excitation/inhibition balance in neural networks and normal brain function.

Several molecular pathways are known to participate in the homeostatic upregulation of excitatory synaptic strength after prolonged reduction of excitatory synaptic transmission (Yu and Goda, 2009; Turrigiano, 2012; Chen et al., 2013). Recent findings show that long-lasting changes in activity also modulate inhibitory transmission in the same cells or systems that express homeostatic changes at excitatory synapses (Kilman et al., 2002; Saliba et al., 2009). This modulation is mediated by changes in the number of postsynaptic $\mathrm{GABA}_{\mathrm{A}}$-receptors $\left(\mathrm{GABA}_{\mathrm{A}} \mathrm{Rs}\right)$ in a reciprocal manner to the changes in excitatory receptors (Saliba et 
al., 2007). However, little is known about the mechanisms of homeostatic changes in synaptic inhibition.

Here, we show that synaptic retinoic acid (RA) signaling plays an essential role in regulating inhibitory synaptic transmission in response to reduced synaptic excitation and that this action of RA involves its function in regulating protein synthesis but not its role as a transcriptional regulator. Thus, RA acts as a central organizer to alter synaptic excitation/inhibition (E/I) balance through its ability to directly modulate both excitatory and inhibitory synaptic strength. We further show that, in the absence of FMRP, RA fails to regulate inhibitory synaptic strength, and suggest that the resulting impact on the synaptic E/I ratio may contribute to Fragile-X syndrome pathogenesis.

\section{Materials and Methods}

Mouse husbandry. The RAR $\alpha$ floxed mouse (C57BL/6 background) is a gift from Drs. Pierre Chambon and Norbert Ghyselinck (IGBMC, Strasbourg, France) (Chapellier et al., 2002) and has been previously described (Sarti et al., 2012). Wild-type and $f \mathrm{mr}^{-/ y}$ mice in the FVB background were obtained from The Jackson Laboratory. Mice of either sex were used for the study.

Drugs and chemicals. The following drugs and chemicals were purchased from Sigma-Aldrich: all-trans RA, actinomycin D, cycloheximide, picrotoxin, and 4-(diethylamino)-benzaldehyde (DEAB). TTX was purchased from Tocris Biosciences, and D-APV from Fisher.

Primary neuronal culture electrophysiology. Rat primary hippocampal neuronal cultures were prepared as previously described (Aoto et al., 2008). Manipulations used to induce scaling of inhibitory transmission included the following: TTX + APV $(1 \mu \mathrm{M}$ TTX $+100 \mu \mathrm{M} \mathrm{APV}, 24 \mathrm{~h})$; RA ( $1 \mu \mathrm{M}, 30$ min followed by 1 h of washout $)$; TTX + CNQX $(1 \mu \mathrm{M}$ TTX + $10 \mu \mathrm{M}$ CNQX, $24 \mathrm{~h})$; and TTX + APV + DEAB $(1 \mu \mathrm{M}$ TTX $+100 \mu \mathrm{M}$ APV + DEAB $10 \mu \mathrm{M}, 24 \mathrm{~h})$. Other drug treatment included the following: preincubation of neurons in anisomycin $(40 \mu \mathrm{M})$, cycloheximide $(100 \mu \mathrm{M})$, or actinomycin D $(50 \mu \mathrm{M})$ for $30 \mathrm{~min}$ before incubation with RA. Dissociated cultures used for dynamin-1 K44E overexpression (gift from Dr. Mark Von Zastrow) and GluR1-C terminal overexpression were transfected using lipofectamine 200 (Invitrogen) at 10-11 DIV with a protocol previously described. Whole-cell patch-clamp recordings were made at room temperature from 14-16 DIV cultured neurons, with 4-6 $\mathrm{M} \Omega$ borosilicate patch pipettes filled with an internal solution containing (in mM) the following: $120 \mathrm{CsCl}, 2 \mathrm{MgCl}_{2}, 5$ EGTA, 10 HEPES, 0.3 $\mathrm{Na}_{3}$-GTP, $4 \mathrm{Na}_{2}$-ATP, pH 7.35. Cultures were continuously superfused with external solution (in $\mathrm{mm}$ ) as follows: $100 \mathrm{NaCl}, 26 \mathrm{NaHCO}_{3}, 2.5$ $\mathrm{KCl}, 11$ glucose, $\left.2.5 \mathrm{CaCl}_{2}, 1.3 \mathrm{MgSO}_{4} 1.0 \mathrm{NaH}_{2} \mathrm{PO}_{4}\right)$. For miniature IPSC (mIPSC) recording, TTX ( $1 \mu \mathrm{M})$, CNQX $(10 \mu \mathrm{M})$, and APV $(50 \mu \mathrm{M})$ were included in the perfusion bath. For mEPSC recordings, bath solution contained TTX $(1 \mu \mathrm{M})$ and picrotoxin $(100 \mu \mathrm{M})$. Cells were held at $-60 \mathrm{mV}$.

Organotypic slices electrophysiology. Hippocampal slice cultures were prepared from RAR $\alpha$ floxed or fmr $1^{-/ y}$ mice at postnatal day 7-8 as described previously (Soden and Chen, 2010). At 1 DIV, CA1 of slices from RAR $\alpha$ floxed mice were injected with lentiviral vectors expressing CRE recombinase or a truncated and inactive version of Cre ( $\Delta$ Cre $)$, gifts from Dr. Thomas Südhof's laboratory (Stanford University, Stanford, CA; Kaeser et al., 2011), together with different rescue truncated versions of RAR $\alpha$. Lentivirus was produced and purified as described previously (Aoto et al., 2008; Sarti et al., 2012). Pharmacological manipulations of cultured hippocampal slices include the following: RA $(2 \mu \mathrm{M}, 4 \mathrm{~h})$ and $\mathrm{TTX}+\mathrm{CNQX}(2 \mu \mathrm{M}+20 \mu \mathrm{M}, 36 \mathrm{~h})$. Whole-cell patch-clamp recordings from the CA1 region of mouse slice cultures were made at room temperature from 6-9 DIV slices with a $4-6 \mathrm{M} \Omega$ borosilicate patch pipette filled with an internal solution containing the following (in mM): $140 \mathrm{CsCl}, 2$ $\mathrm{MgCl}_{2}, 5$ EGTA, 10 HEPES, $0.3 \mathrm{Na}_{3}-\mathrm{GTP}$, and $4 \mathrm{Na}_{2}-\mathrm{ATP}, \mathrm{pH}$ 7.35. Slices were continuously superfused with external solution containing the following (in mM): $120 \mathrm{NaCl}, 26 \mathrm{NaHCO}_{3}, 2.5 \mathrm{KCl}, 11$ glucose, $2.5 \mathrm{CaCl}_{2}$, $1.3 \mathrm{MgSO}_{4}$, and $1.0 \mathrm{NaH}_{2} \mathrm{PO}_{4}$. CNQX $(10 \mu \mathrm{M})$ and APV $(50 \mu \mathrm{M})$ were included in the external saline solution. The stimulating electrodes were placed over CA1 stratum radiatum. Synaptic GABA-mediated responses were measured at $-60 \mathrm{mV}$ from two adjacent pair of cells where one was infected by the lentiviral vector expressing CRE or $\triangle$ CRE recombinase alone or in combination with RAR $\alpha$ rescue constructs. Synaptic responses in cell pairs were averaged over $40-50$ trials with an interval of $10 \mathrm{~s}$.

Acute slice electrophysiological recordings. Ten-day-old mice were anesthetized with $\mathrm{CO}_{2}$, and the brains were quickly removed into ice-cold high sucrose solution (HSS) containing the following (in mM): $75 \mathrm{NaCl}$, $2.5 \mathrm{KCl}, 1.25 \mathrm{NaH}_{2} \mathrm{PO}_{4}, 26 \mathrm{NaHCO}_{3}, 25$ glucose, 75 sucrose, $4 \mathrm{MgCl}_{2}$, and $0.5 \mathrm{CaCl}_{2}$. Coronal slices of $400 \mu \mathrm{m}$ were made with a vibratome (Leica, VT1200) in HSS. After cutting, slices were immediately moved to $32-34^{\circ} \mathrm{C}$ artificial CSF (ACSF) containing the following (in $\mathrm{mm}$ ): 120 $\mathrm{NaCl}, 26 \mathrm{NaHCO}_{3}, 2.5 \mathrm{KCl}, 11$ glucose, $2 \mathrm{CaCl}_{2}, 2 \mathrm{MgSO}_{4}$, and 1.0 $\mathrm{NaH}_{2} \mathrm{PO}_{4}$. ACSF and HSS are balanced with $5 \% \mathrm{CO}_{2}$ and $95 \% \mathrm{O}_{2}$. Slices were allowed to recover at $32-34^{\circ} \mathrm{C}$ for $30 \mathrm{~min}$, after which the slices were moved to the room temperature. RA $(2 \mu \mathrm{M})$ was added to the incubating ACSF at room temperature. To compensate for the loss of RA resulting from oxidation by bubbling with $5 \% \mathrm{CO}_{2} / 95 \% \mathrm{O}_{2}$, two additional supplements of RA $(2 \mu \mathrm{M})$ were added $45 \mathrm{~min}$ and $90 \mathrm{~min}$ after the first treatment. Electrophysiology recordings were done between 2 and $4 \mathrm{~h}$ after the first RA treatment. Whole-cell voltage-clamp recordings in CA1 pyramidal neurons were made using borosilicate glass pipettes with tip resistance 3-5 M $\Omega$. mIPSCs were recorded at a holding potential of -60 $\mathrm{mV}$, in the presence of $1 \mu \mathrm{M}$ TTX, $10 \mu \mathrm{M}$ CNQX, and $50 \mu \mathrm{M} \mathrm{DAPV}$, with an internal solution containing the following (in $\mathrm{mm}$ ): $140 \mathrm{CsCl}, 2$ $\mathrm{MgCl}_{2}, 5$ EGTA, 10 HEPES, $4 \mathrm{Na}_{2} \mathrm{ATP}, 0.4 \mathrm{Na}_{3} \mathrm{GTP}, \mathrm{pH}$ 7.25-7.3. For E/I ratio experiments, we used an internal solution containing the following (in mM): $132 \mathrm{CsMeSO}_{3}, 8 \mathrm{CsCl}, 10$ HEPES, 0.6 EGTA, 4 MgATP, 0.4 $\mathrm{Na}_{3} \mathrm{GTP}$, and $10 \mathrm{Na}$-phosphocreatine (pH adjusted to 7.25-7.30 with $\mathrm{CsOH}$ ). A glass pipette filled with $1 \mathrm{M} \mathrm{NaCl}$ was used as the stimulating electrode, driven by an isolated pulse generator (A-M Systems, model 2100). A separate $\mathrm{Ag} / \mathrm{AgCl}$ wire in the recording chamber was used as the ground for stimulation. EPSCs were recorded at $-67 \mathrm{mV}$ (measured reversal potential of IPSC), and IPSCs at $5 \mathrm{mV}$ (measured reversal potential of EPSC). EPSCs/IPSCs were averaged over 15-30 trials with an interval of $10 \mathrm{~s}$. The Ge, Gi, and the Ge/Gi ratio was calculated for individual neurons, and then $\mathrm{Ge} / \mathrm{Gi}$ was averaged within a group. The simulation of EPSC/IPSC used the assumption of $\mathrm{V}_{\mathrm{EPSC}}=0 \mathrm{mV}, \mathrm{V}_{\mathrm{IPSC}}=-65$ $\mathrm{mV}$, and that no nonsynaptic active membrane conductance was engaged by synaptic excitation at $-60 \mathrm{mV}$ and $-50 \mathrm{mV}$.

All electrophysiological recordings were performed with Multiclamp 700A/B amplifiers and analyzed using Clampfit (Axon Laboratories) and Mini Analysis Program (Synaptosoft).

Surface biotinylation assay. Biotinylation of surface proteins was performed as previously described (Aoto et al., 2008). Briefly, cultured hippocampal cells were biotinylated with $1 \mathrm{mg} / \mathrm{ml}$ Ez-link sulfo-NHSSS-biotin (Pierce). Biotinylated cells were solubilized with lysis buffer (PBS with 1\% Triton-X, 1\% NP-40, 10\% glycerol, $25 \mathrm{~mm} \mathrm{MgCl}_{2}$, and a protease inhibitor mixture). Lysate was bound for $3 \mathrm{~h}$ at $4^{\circ} \mathrm{C}$ using Ultralink-immobilized streptavidin beads to precipitate biotinylated proteins. Biotinylated surface proteins were eluted with denaturing buffer at $75^{\circ} \mathrm{C}$. Surface-expressed $\mathrm{GABA}_{\mathrm{A}}$ receptors were detected by Western blot analysis using anti- $\beta 3$ antibody (Abcam).

Immunocytochemistry, receptor internalization assay, and image analysis. We followed procedures previously described (Tracy et al., 2011). For surface staining, coverslips were fixed in $4 \%$ PFA and then incubated in blocking solution containing $2 \%$ normal goat serum. Primary antibodies were added to the cells followed by flourophore-conjugated secondary antibodies. The primary antibody against the extracellular domain of $\mathrm{GABA}_{\mathrm{A}}$ receptors subunit $\beta 2 / 3$ was purchased from Millipore. For total receptor staining, cells were fixed with $4 \%$ PFA, then permeabilized with blocking solution containing Triton X-100 0.3\% and normal goat serum $2 \%$. Images were acquired using Olympus FV1000 BX61WI laserscanning confocal microscope, using an Olympus Plan Apochromat with sequential acquisition setting at $1024 \times 1024$ pixel resolution. Puncta staining was analyzed as described previously (Tracy et al., 2011). For the analysis of synaptic proteins, images from the same experiment were thresholded identically by intensity to exclude the diffuse/intracellular 

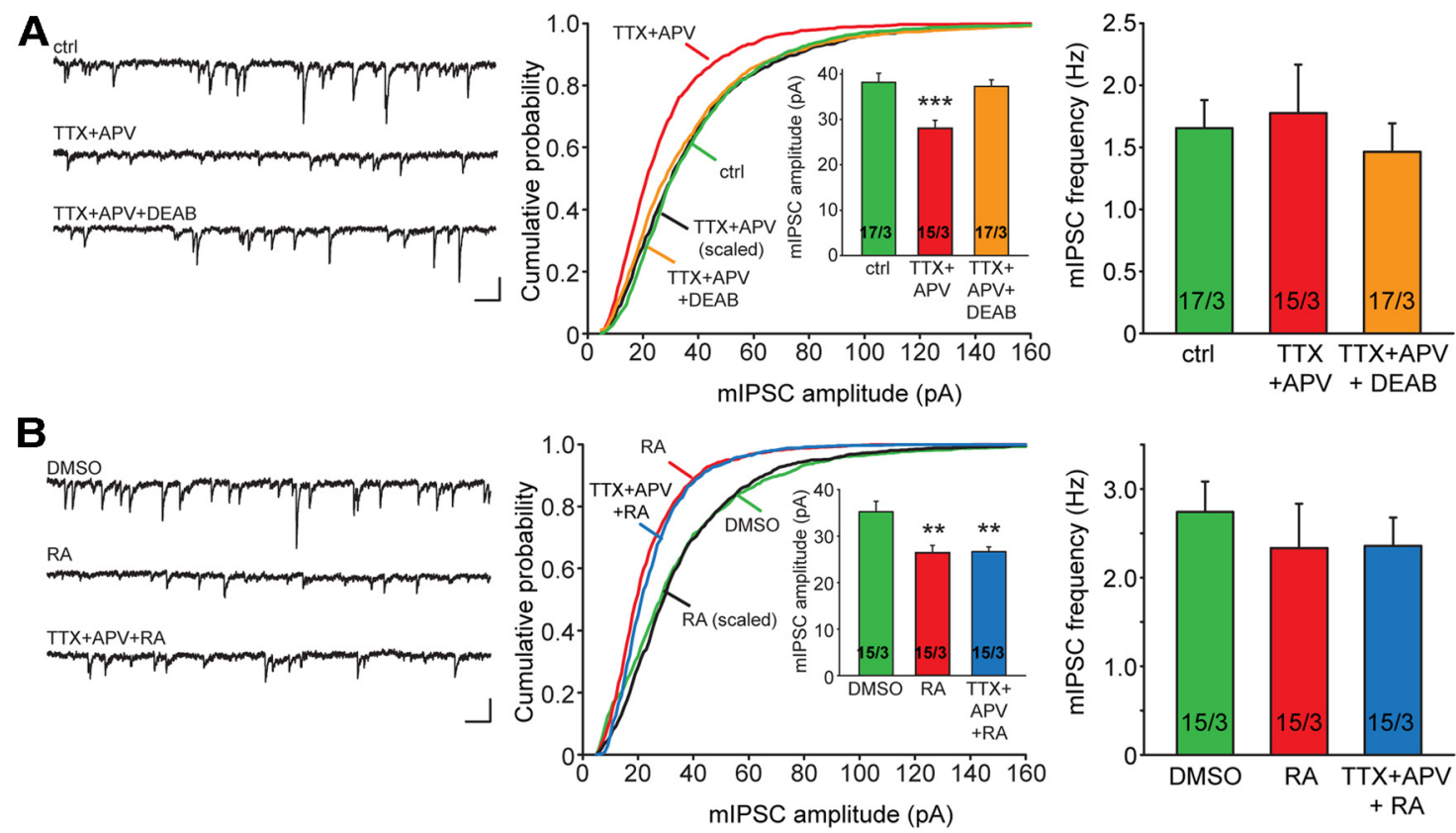

Figure 1. RA mediates homeostatic downscaling of inhibitory synaptic transmission. $A$, Representative traces (left) and quantification of mIPSC amplitude (middle) and frequency (right) recorded from cultured rat hippocampal neurons treated with control vehicle, TTX + APV (24 h), or TTX + APV + DEAB (24 h). ${ }^{* * *} p<0.001 . B$, Representative traces (left) and quantification (middle and right) of mIPSCs recorded from cultured neurons treated with DMSO, RA (1 $\mu \mathrm{M}, 0.5 \mathrm{~h})$, or TTX + APV ( $24 \mathrm{~h}$ ) followed by RA (0.5 h). ${ }^{* *} p<0.01$.

pool. Synaptic colocalization was defined as a minimum 2-pixel overlap between the VGAT signal and the $\mathrm{GABA}_{\mathrm{A}} \mathrm{R} \beta 2 / 3$ signal. Image quantification was performed blind to treatment group using MATLAB (MathWorks).

In receptor internalization experiments, neurons were incubated with antibody against the extracellular domain of the $\beta 2 / 3$ subunit at $37^{\circ} \mathrm{C}$ for $15 \mathrm{~min}$. Cells were successively washed thoroughly and incubated with either DMSO or RA and fixed at different time points. After the extracellular antibody was revealed with a secondary antibody coupled with $\mathrm{Cy} 3$, cells were permeabilized with blocking solution containing Triton X-100 0.3\% and normal goat serum $2 \%$. Internalized receptors were revealed by applying a secondary antibody coupled to Cy2. Map2 was used as a dendritic marker. Images were acquired and analyzed as described above.

Statistical analysis. All graphs represent mean \pm SEM values. For each experimental group, $N$ and $n$ represent number of independent experiments and total number of neurons, respectively, and are indicated in the figures. Single-factor ANOVA is used for statistical analysis.

\section{Results}

Activity blockade-induced downscaling of inhibitory synaptic transmission is mediated by RA

Similar to previous reports (Kilman et al., 2002; Saliba et al., 2009), we observed that suppressing neuronal activity with TTX + APV effectively downscales synaptic inhibition (Fig. 1A). Treating cultured hippocampal
A
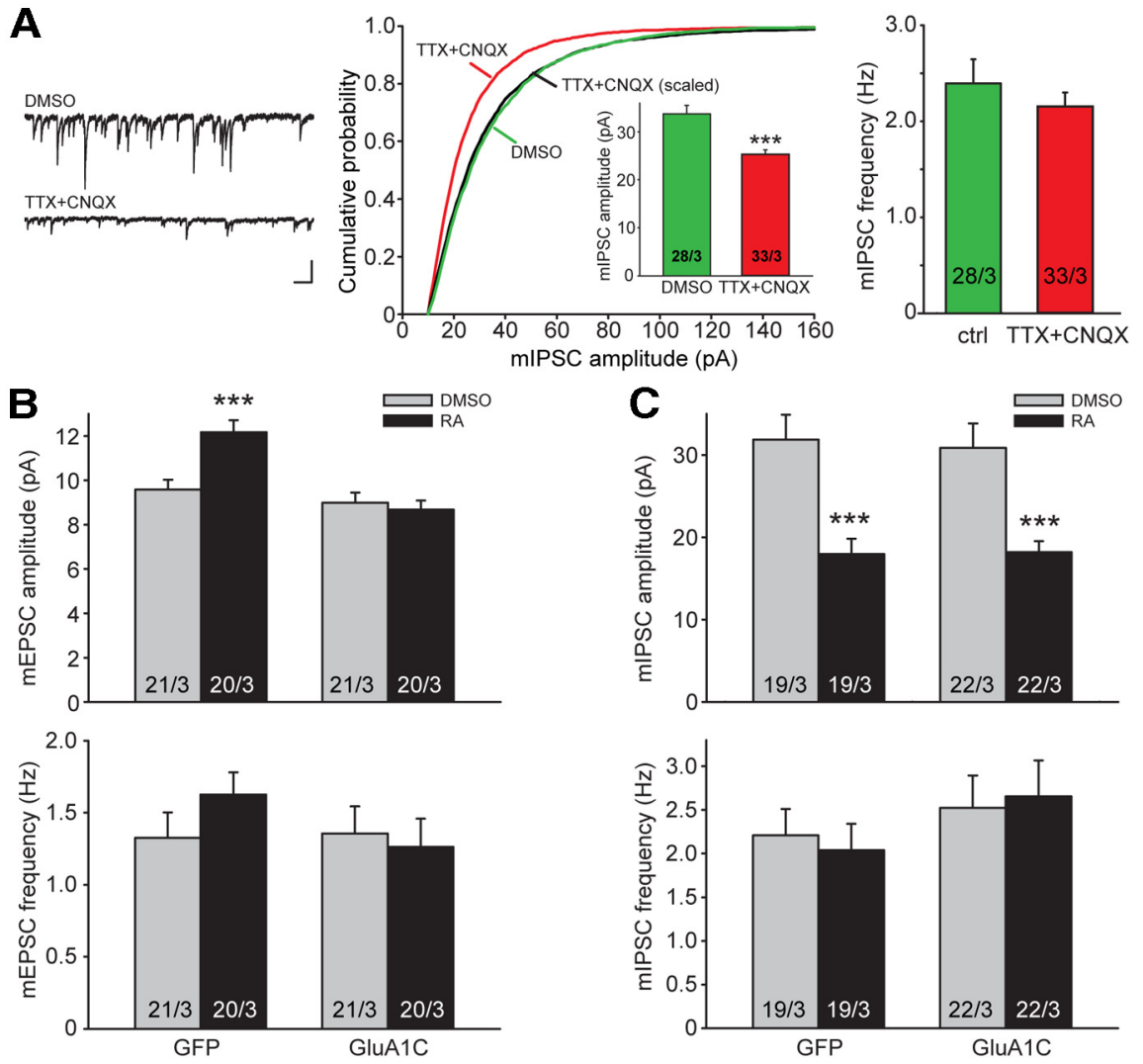

Figure 2. Downscaling of synaptic inhibition is independent of upscaling of synaptic excitation. $\boldsymbol{A}$, Inhibitory synaptic scaling induced by TTX + CNQX (24 h). ${ }^{* *} p<0.001$. B, Average mEPSC amplitude and frequency from cultured neurons overexpressing the C-terminal domain of GluR1 and treated with DMSO or $1 \mu \mathrm{M} \mathrm{RA.}{ }^{* * *} p<0.001$. C, Average amplitude and frequency of mIPSCs from neurons overexpressing GluR1 C-terminal domain and treated with DMSO or $1 \mu \mathrm{M}$ RA. ${ }^{* * *} p<0.001$. 
A

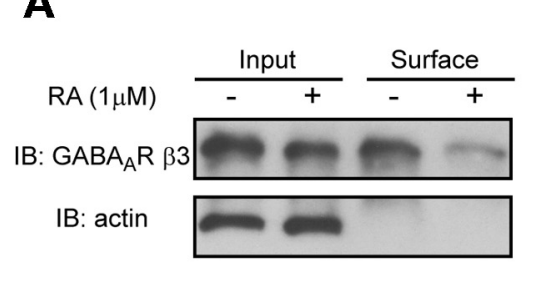

C
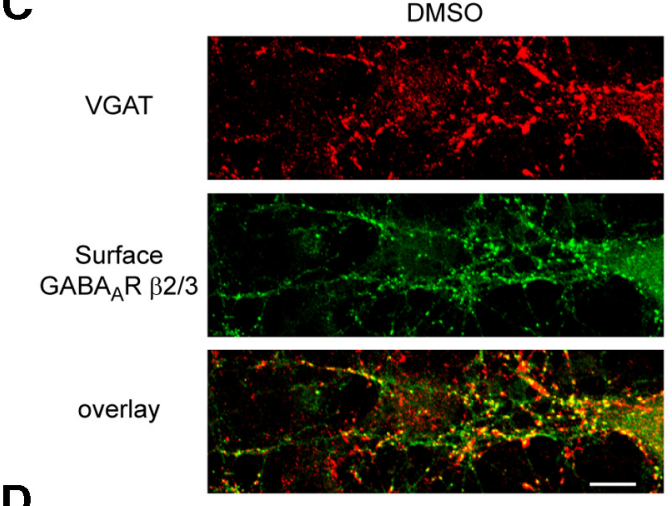

B

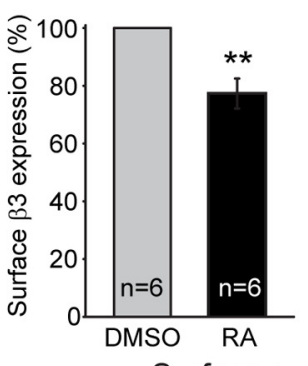

Surface synaptic $G A B A_{A} R$ staining

\section{B}
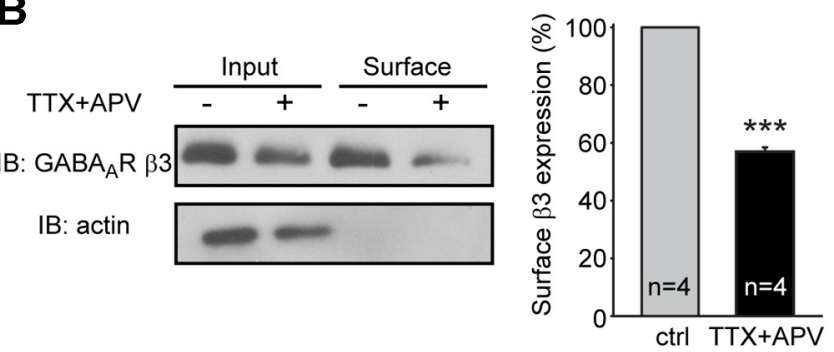

RA
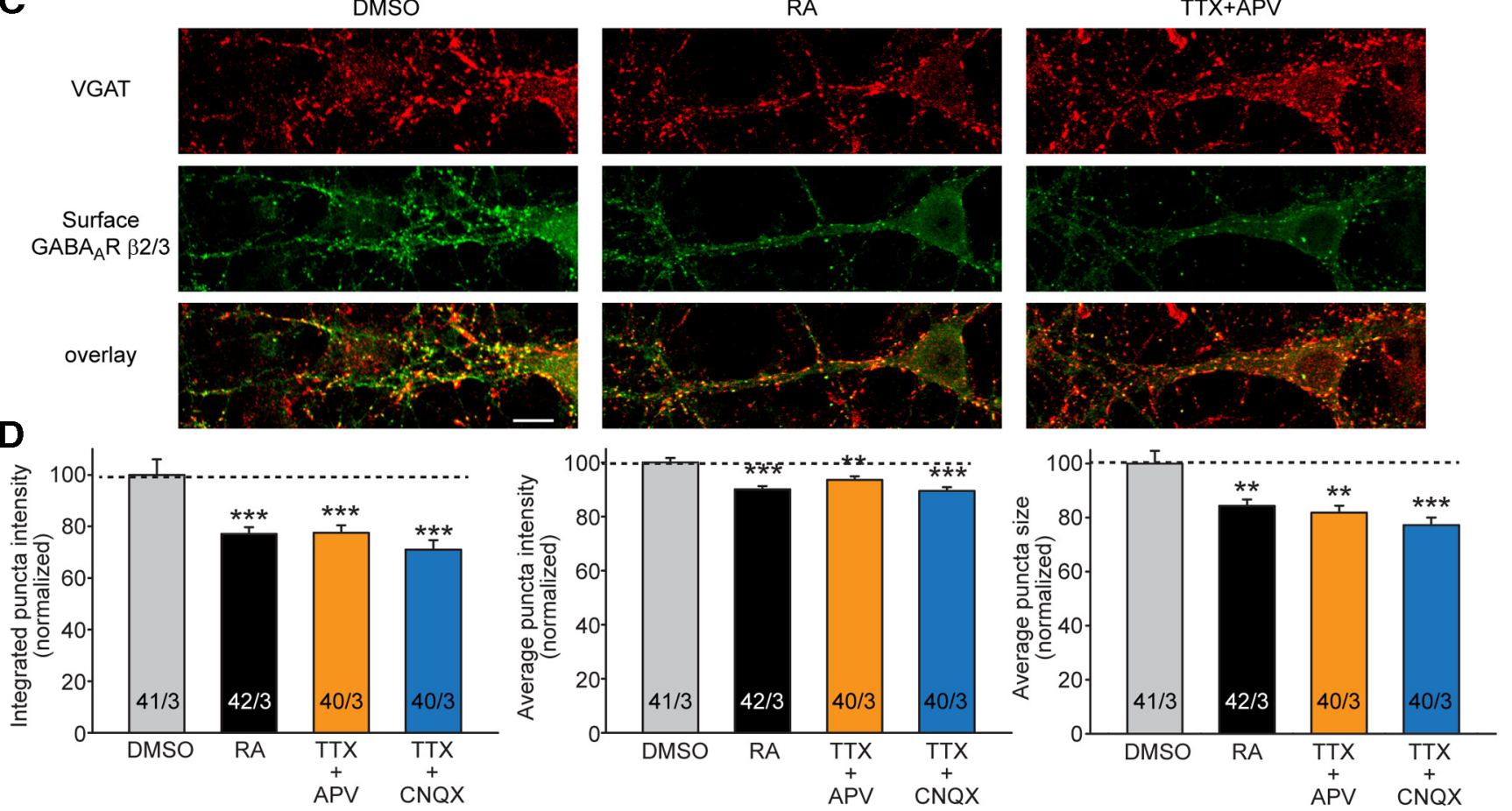

Figure 3. Activity blockade or RA treatment led to a loss of total synaptic and surface $G A B A_{A}$ receptors. $A$, Surface biotinylation assay for $G A B A_{A} R \beta 3$ subunit in cultured hippocampal rat neurons treated with RA. ${ }^{* *} p<0.01$. B, Surface biotinylation assay for $G A B A_{A} R \beta 3$ subunit in cultured neurons during activity blockade with TTX + APV. ${ }^{* * *} p<0.0001$. C, Immunolabeling of surface $\beta 2 / 3$ subunit containing GABA $\mathrm{Rs}$ (green) and VGAT (red) from 14 DIV rat hippocampal neurons treated with RA (1.5 h), TTX + APV ( $24 \mathrm{~h}$ ), or TTX + CNQX (24 h). Scale bar, $10 \mu \mathrm{m}$. D, Quantification of synaptic GABA $A_{A} R \beta 2 / 3$ punta (colocalized with VGAT). ${ }^{* *} p<0.01 .{ }^{* * *} p<0.001$.

neurons with TTX + APV for 24 h significantly reduced the average amplitude of mIPSCs (control, $38.17 \pm 2.00 \mathrm{pA}$; TTX + $\mathrm{APV}, 28.03 \pm 1.77 \mathrm{pA}, p<0.001)$ without affecting the mIPSC frequency (control, $1.66 \pm 0.23 \mathrm{~Hz}$; TTX $+\mathrm{APV}, 1.78 \pm 0.39$ $\mathrm{Hz}$ ). Importantly, DEAB, a blocker of the RA synthesizing enzyme retinal dehydrogenase (Russo et al., 1988; Wang et al., 2011), prevented the downscaling of mIPSCs induced by TTX + APV treatment (amplitude, $37.29 \pm 1.41 \mathrm{pA}$; frequency, $1.47 \pm 0.23 \mathrm{~Hz}$ ) (Fig. $1 A$ ), suggesting that RA synthesis is required for the downscaling of synaptic inhibition in addition to upscaling of synaptic excitation.

We next asked whether RA directly modulates inhibitory synaptic responses. Brief RA treatment (30 min RA +60 min wash) in cultured hippocampal neurons led to a robust decrease in mIPSC amplitude (control, $35.18 \pm 2.30 \mathrm{pA}$; RA, $26.39 \pm 1.60$ $\mathrm{pA}, p<0.01$ ) without affecting the mIPSC frequency (control, $2.74 \pm 0.34 \mathrm{~Hz}$; RA, $2.33 \pm 0.5 \mathrm{~Hz}$ ) (Fig. $1 B$ ). Addition of RA to neurons that had been treated with TTX + APV for $24 \mathrm{~h}$ did not further decrease the mIPSC amplitude (amplitude, 26.63 \pm 1.10 pA; frequency, $2.33 \pm 0.32 \mathrm{~Hz}$ ) (Fig. $1 B$ ), indicating that prior chronic TTX + APV treatment occludes RA-induced downscaling of synaptic inhibition.
These results, together with previous studies showing that reduced excitatory synaptic activity leads to rapid synthesis of RA in neurons (Wang et al., 2011), establish a direct role of RA in the downscaling of synaptic inhibition upon activity blockade.

\section{Downscaling of mIPSCs is not dependent on upscaling of mEPSCs}

We next asked whether RA downscales inhibitory synaptic strength indirectly via upscaling of excitatory synaptic transmission. We first tested whether downscaling of mIPSCs still occurred when AMPA receptor (AMPAR) activity was blocked by a selective antagonist (CNQX). We used an activity blockade protocol (TTX + CNQX) that robustly induces synaptic upscaling and blocks both preexisting and newly inserted AMPARs, with the latter as a result of homeostatic scaling (Jakawich et al. 2010; Wang et al., 2011). After $24 \mathrm{~h}$ TTX + CNQX treatment, cultured neurons were transferred to ACSF containing TTX + CNQX + APV for mIPSC recordings. We found that the mIPSC amplitude, but not the mIPSC frequency, was again significantly decreased (DMSO, $33.75 \pm 1.72 \mathrm{pA}, 2.39 \pm 0.25 \mathrm{~Hz}$; TTX + CNQX, $25.31 \pm 0.91 \mathrm{pA}, 2.15 \pm 0.15 \mathrm{~Hz}, p<0.001$ ) (Fig. $2 A$ ). Because CNQX was present throughout the treatment and recording pe- 

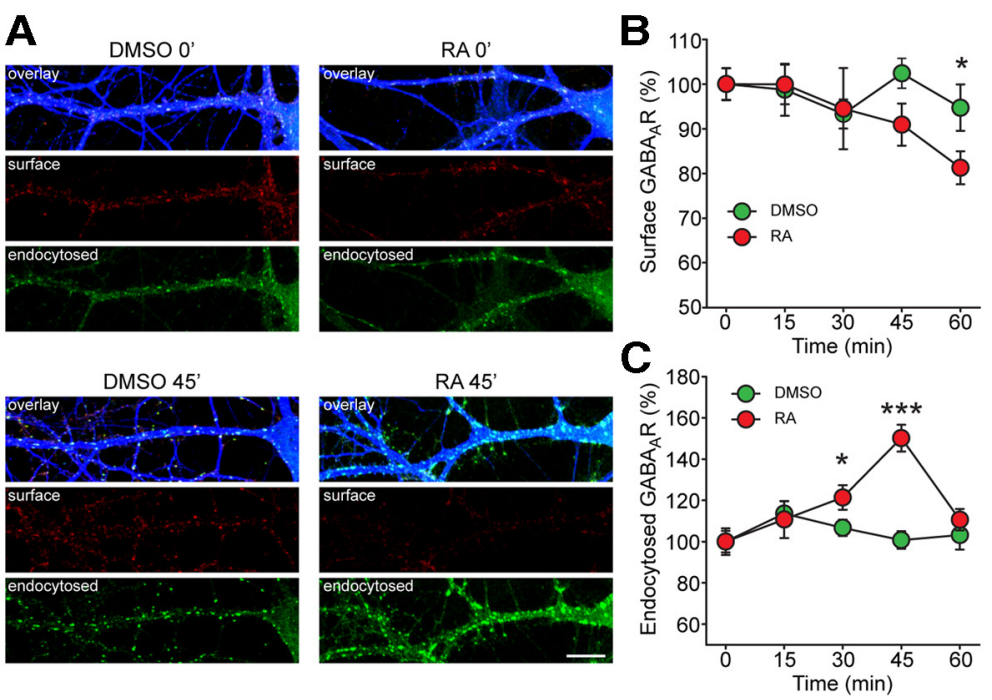
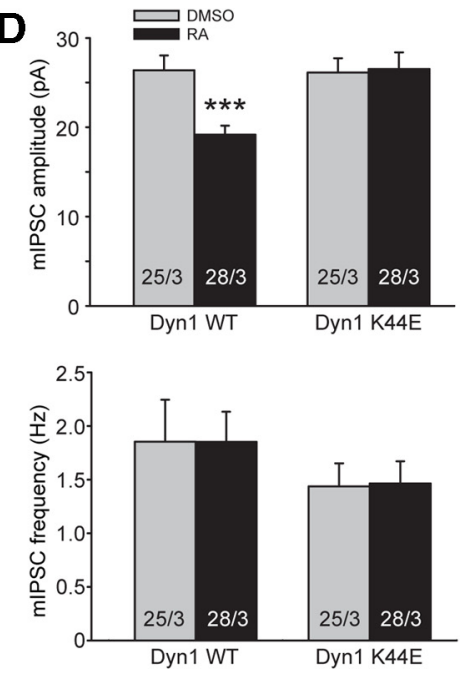

Figure 4. RA treatment enhances endocytosis of surface $G A B A_{A} R s$. $A$, Representative images of endocytosis assay. Neurons were live-labeled with GABA $R$ R $\beta 2 / 3$ antibody, treated with $D M S 0$ or $R A$, and then fixed at different time points and stained for endocytosed (green) and remaining surface (red) GABA Rs. Dendritic branches are labeled with MAP2 (blue). Scale bar, $10 \mu \mathrm{m}$. $\boldsymbol{B}$, Quantification of remaining surface $G A B A_{A} R$ (normalized to time 0 ) at different time points after DMSO or RA treatment $(n / N=25-34 / 3)$ ) ${ }^{*} p<0.05$. C, Quantification of endocytosed GABA $A_{A} R$ (normalized to time 0 ) at different time points after DMSO or RA treatment $(n / N=25-34 / 3) .{ }^{*} p<0.05 .{ }^{* * *} p<0.001$. D, mIPSC amplitude (top) and frequency (bottom) analysis from neurons overexpressing either wild-type dynamin-1 or the dominant-negative K44E, and treated with DMSO or RA. ${ }^{* * *} p<0.0001$. All graphs represent mean \pm SEM. $n / N$ indicates number of cells/number of independent experiments.

riod, increases in synaptic AMPAR responses could not have caused the downscaling of synaptic inhibition.

It is possible that physical insertion (and not activity per se) of AMPARs into synapses mediates RA-dependent downscaling of synaptic inhibition through an unknown interaction. To test this possibility, we transfected a GFP-tagged C-terminal fragment of GluA1 (GluA1C) into cultured hippocampal neurons. Overexpression of GluA1C blocks activity-dependent synaptic trafficking of AMPARs (Shi et al., 2001; Haas et al., 2006). We first asked whether expression of GluA1C blocked synaptic upscaling of mEPSCs. Indeed, compared with GFP-transfected neurons, which exhibited a significant increase in mEPSC amplitude in response to acute RA treatment (DMSO, $9.59 \pm 0.44 \mathrm{pA}$; RA, $12.17 \pm 0.55 \mathrm{pA}, p<0.001)$, GluA1C-expressing neurons failed to respond to RA treatment (DMSO, $8.99 \pm 0.46 \mathrm{pA}$; RA, $8.68 \pm$ $0.41 \mathrm{pA}$ ) (Fig. $2 B$ ). By contrast, in the same experiments, the RA-dependent downscaling of mIPSCs was not affected by GluA1C overexpression (GFP/DMSO, $31.20 \pm 3.06$ pA; GFP/RA, $18.00 \pm 1.86 \mathrm{pA}$; GluA1C/DMSO, $30.46 \pm 2.98$ pA; GluA1C/RA, $18.35 \pm 1.35 \mathrm{pA}, p<0.001$ ) (Fig. 2C). The frequency of mEPSCs and mIPSCs was not affected by GluA1C overexpression or by RA treatment (Fig. $2 B, C$ ).

Together, these data indicate that upscaling of excitatory synaptic transmission and downscaling of inhibitory synaptic transmission are independent parallel processes triggered by RA.

\section{Reduced $\mathrm{GABA}_{\mathrm{A}} \mathrm{R}$ abundance underlies homeostatic downscaling of synaptic inhibition}

How does RA reduce synaptic inhibition? The lack of a change in mIPSC frequency suggests a postsynaptic mechanism (i.e., reduced postsynaptic $\mathrm{GABA}_{\mathrm{A}} \mathrm{R}$ abundance). We therefore performed surface protein biotinylation experiments to examine the surface abundance of $\mathrm{GABA}_{\mathrm{A}} \mathrm{Rs}$ after RA treatment or activity blockade. Both acute RA and chronic activity blockade with TTX + APV significantly reduced the amount of $\mathrm{GABA}_{\mathrm{A}} \mathrm{Rs}$ on the neuronal surface $(\mathrm{RA}, 77.3 \pm 5.20 \%$ of
DMSO control, $p<0.01$; TTX + APV, $56.82 \pm 1.67 \%$ of vehicle control, $p<0.001$ ) (Fig. $3 A, B$ ).

To further examine whether the synaptic abundance of $\mathrm{GABA}_{\mathrm{A}} \mathrm{Rs}$ is affected by RA- or activity blockade-induced downscaling of synaptic inhibition, we performed immunocytochemistry experiments that measured the abundance of synaptic surface-exposed $\mathrm{GABA}_{\mathrm{A}}$ Rs. We used an antibody to $\mathrm{GABA}_{\mathrm{A}} \mathrm{R}$ $\beta 2 / 3$ subunits that recognizes an extracellular epitope to probe surface receptors in nonpermeabilized neurons, using vesicular GABA transporter (vGAT) immunolabeling as a general marker for inhibitory synapses. Both acute RA treatment and chronic activity blockade significantly reduced the synaptic abundance of $\mathrm{GABA}_{\mathrm{A}} \mathrm{R}$, manifested as reduced integrated puncta intensity (DMSO, $100 \pm 6.03 \%$; RA, $77.04 \pm 2.70 \%$; TTX + APV, $77.49 \pm$ 2.93\%; TTX + CNQX, $71.04 \pm 3.62 \%$; ${ }^{* *} p<0.001$ ), average puncta intensity (DMSO, $100 \pm 1.70 \%$; RA, $90.08 \pm 1.19 \%$; TTX + APV, $93.57 \pm 1.26 \%$; TTX + CNQX, $89.45 \pm 1.46 \%$; $\left.{ }^{* *} p<0.05 ;{ }^{* *} p<0.001\right)$, and puncta size (DMSO, $100 \pm 4.66 \%$; RA, $84.28 \pm 2.37 \%$; TTX + APV, $81.8 \pm 2.61 \%$; TTX + CNQX, $77.14 \pm 2.85 \% ;^{* *} p<0.05 ;{ }^{* * *} p<0.001$ ) (Fig. $3 C, D$ ). The same observations were made when the staining was performed under permeabilized conditions to examine the total abundance of synaptic $\mathrm{GABA}_{\mathrm{A}} \mathrm{Rs}$ (data not shown). We also analyzed vGAT signals and found that none of the treatment significantly alter the vGAT puncta intensity, size, or density (data not shown). The RAinduced reduction in synaptic abundance of $\mathrm{GABA}_{\mathrm{A}}$ Rs corroborates our observation that RA decreases mIPSC amplitudes (Fig. $1 B$ ) and also leads to a decrease in evoked IPSC (eIPSC) amplitudes (see below).

Surface $\mathrm{GABA}_{\mathrm{A}}$ Rs are constantly recycled (Kittler et al., 2000). Therefore, the reduced synaptic abundance of $\mathrm{GABA}_{\mathrm{A}}$ Rs could be caused by enhanced endocytosis or reduced exocytosis of $\mathrm{GABA}_{\mathrm{A}}$ Rs. To distinguish between these two possibilities, we directly measured surface $\mathrm{GABA}_{\mathrm{A}} \mathrm{R}$ endocytosis using antibody labeling for $\mathrm{GABA}_{\mathrm{A}} \mathrm{Rs}$ in live neurons. After a $15 \mathrm{~min}$ incubation at $37^{\circ} \mathrm{C}$ with a primary antibody recognizing the $\beta 2 / 3$ subunit of 
A
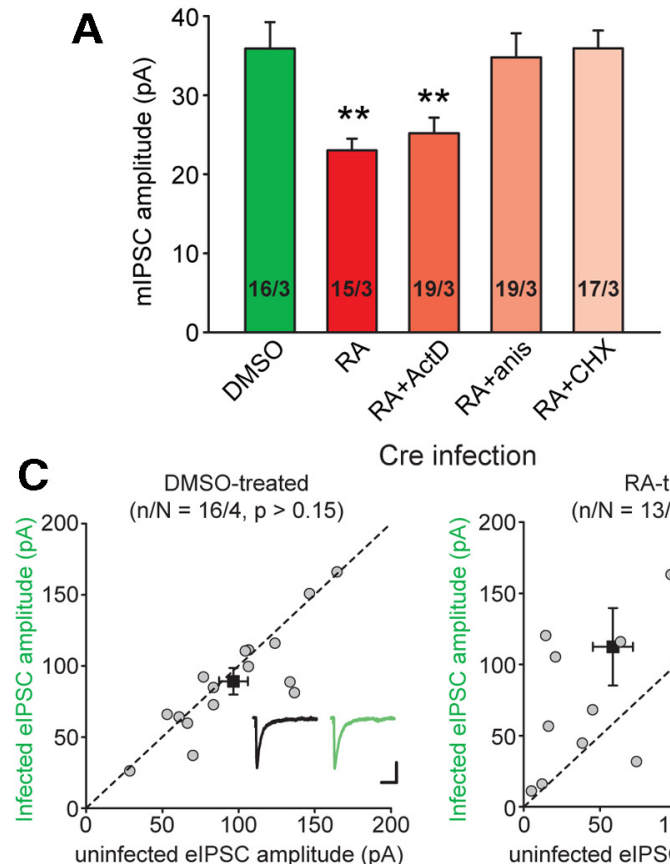

Cre infection

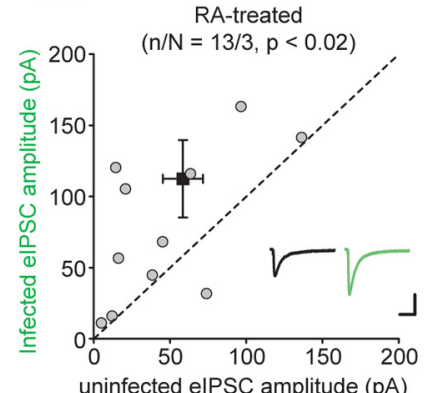

Cre + LBD/F infection
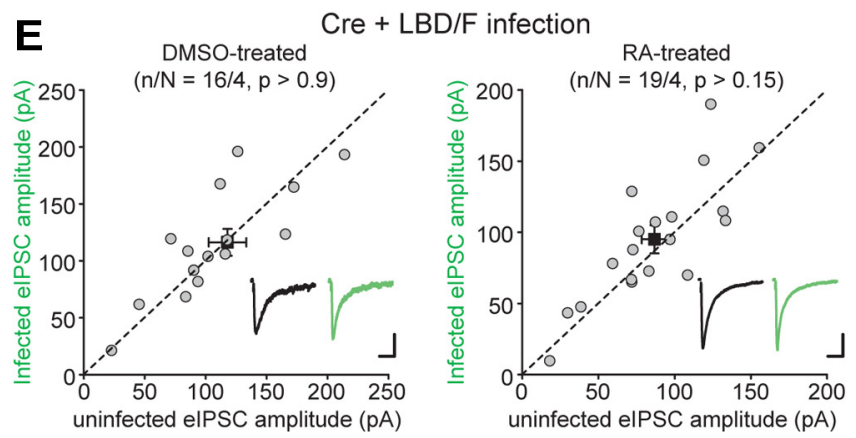

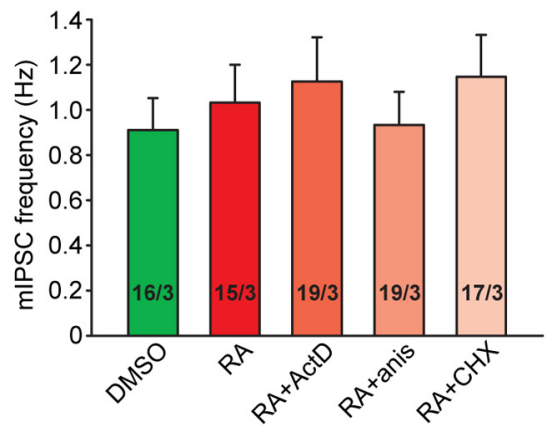

B

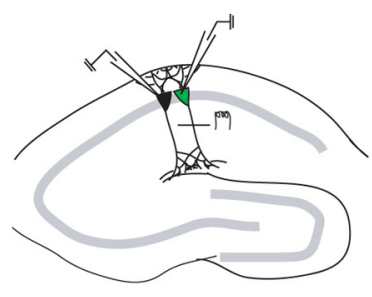

$\Delta$ Cre infection

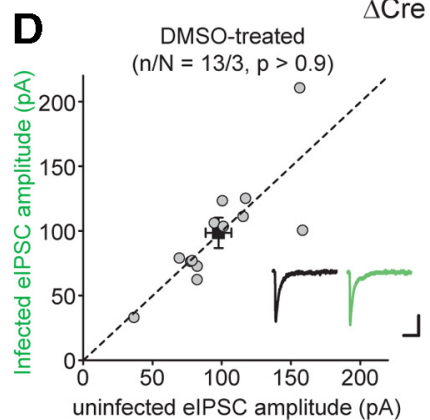

RA-treated

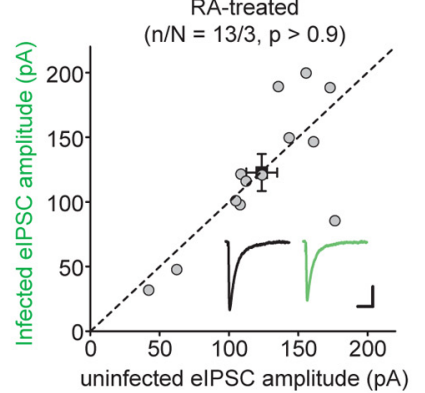

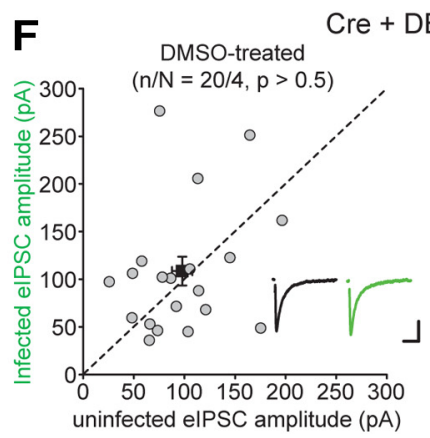

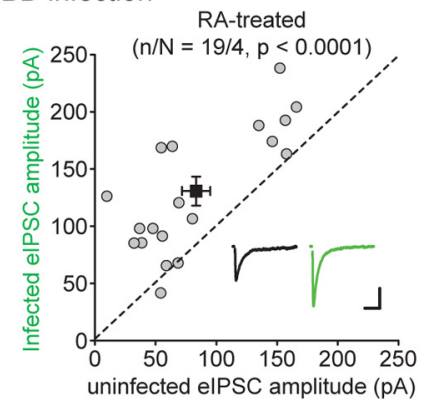

Figure 5. New protein synthesis and non-nuclear functions of RAR $\alpha$ are required for downscaling of inhibitory synaptic transmission. A, Amplitude and frequency analysis of mIPSCs obtained from rat hippocampal neurons cotreated with transcription (actinomycin) or translation (anisomycin, cycloheximide) inhibitors and RA. ${ }^{* *} p<0.01 . B$, Recording configuration for paired recordings of elPSCs. Cultured hippocampal slices from RAR $\alpha$ floxed mouse were infected with Cre-expressing lentivirus. Paired recordings of elPSCs were obtained simultaneously from two neighboring CA1 pyramidal neurons: one infected (green), one uninfected (black). The stimulating electrodes were positioned in stratum radiatum as shown. $C-\boldsymbol{F}$, Scatter plots of elPSCs from individual pairs (gray circles) and group mean \pm SEM (black squares) of simultaneously recorded neurons. Insets, Representative traces for infected neurons (green) and RAR $\alpha$ floxed neurons (black) recorded after treatment with RA or DMSO. Neurons were infected with a lentiviral vector expressing the following: $(\boldsymbol{C})$ Cre recombinase (to generate RAR $\alpha$ KO neurons); (D) inactive recombinase $\Delta$ (re; $(\boldsymbol{E})$ Cre and RAR $\alpha$ LBD/F; and $(\boldsymbol{F})$ Cre and RAR $\alpha$ DBD. Calibration: $40 \mathrm{pA}, 100 \mathrm{~ms} . n / N$ indicates number of cells/number of independent experiments.

$\mathrm{GABA}_{\mathrm{A}}$ Rs, neurons were treated with DMSO or RA for an additional 15, 30, 45, and $60 \mathrm{~min}$. The remaining surface localized and internalized $\beta 2 / 3$ receptors were labeled in the neurons after fixation without and with permeabilization. Consistent with the results from the immunostaining of synaptic $\mathrm{GABA}_{\mathrm{A}} \mathrm{Rs}$ (Fig. $3 C, D)$, RA treatment significantly reduced surface $\mathrm{GABA}_{\mathrm{A}} \mathrm{Rs}$ at the 60 min time point (DMSO, $94.71 \pm 5.21 \%$; RA, $81.25 \pm$ $3.70 \% ; p<0.05$ ) (Fig. $4 A, B$ ). Importantly, although surface $\mathrm{GABA}_{\mathrm{A}}$ Rs are fairly stable upon DMSO treatment, RA treatment significantly increased the proportion of endocytosed $\mathrm{GABA}_{\mathrm{A}} \mathrm{Rs}$ at the earlier time points of $<60 \mathrm{~min}$ (30 min: DMSO, $106.70 \pm$ $4.00 \%, \mathrm{RA}, 121.41 \pm 5.97 \%, p<0.05 ; 45 \mathrm{~min}$ : DMSO, $100.75 \pm$ $4.25 \%$, RA, $150.18 \pm 6.53 \% ; p<0.001$ ) (Fig. $4 B, C$ ). We observed a significant decrease in the endocytosed $\mathrm{GABA}_{\mathrm{A}} \mathrm{R}$ pool in the RA group at the $60 \mathrm{~min}$ time point (Fig. $4 \mathrm{C}$ ), probably because of lysosomal degradation of internalized receptors (Kittler et al., 2004).

We next asked whether blocking clathrin-mediated endocytosis by overexpression of a dominant-negative mutant of dynamin I (the K44E substitution) (Chu et al., 1997) blocks RA's effect on
mIPSCs. Dynamin WT or mutant constructs were cotransfected with GFP in 10-11 DIV cultured neurons, and recordings were performed $3 \mathrm{~d}$ later. Dynamin I K44E overexpression has been previously reported to increase $\mathrm{GABA}_{\mathrm{A}} \mathrm{R}$ surface density in a mammalian cell line (Herring et al., 2003), but no effect of mutant dynamin on basal inhibitory transmission in cultured neurons has been described previously. Here, we found that basal transmission was not affected by overexpressing the dominantnegative K44E (DMSO treated: WT dynamin I, $26.39 \pm 1.65 \mathrm{pA}$; dynamin I K44E, $26.13 \pm 1.58$ pA) (Fig. 4D). However, dynamin I K44E-expressing neurons failed to respond to RA treatment (RA treated: WT dynamin I, $19.17 \pm 1.02 \mathrm{pA}, p<0.001$; dynamin I K44E, $26.52 \pm 1.87 \mathrm{pA}$ ) (Fig. 4D). Thus, endocytosis of $\mathrm{GABA}_{\mathrm{A}} \mathrm{R}$ is required for synaptic downscaling.

\section{Nongenomic action of RA/RAR $\alpha$ mediates the downscaling of synaptic inhibition}

The effect of RA on excitatory synaptic transmission is mediated by a novel mechanism that does not require transcriptional regulation but operates through translational derepression of 

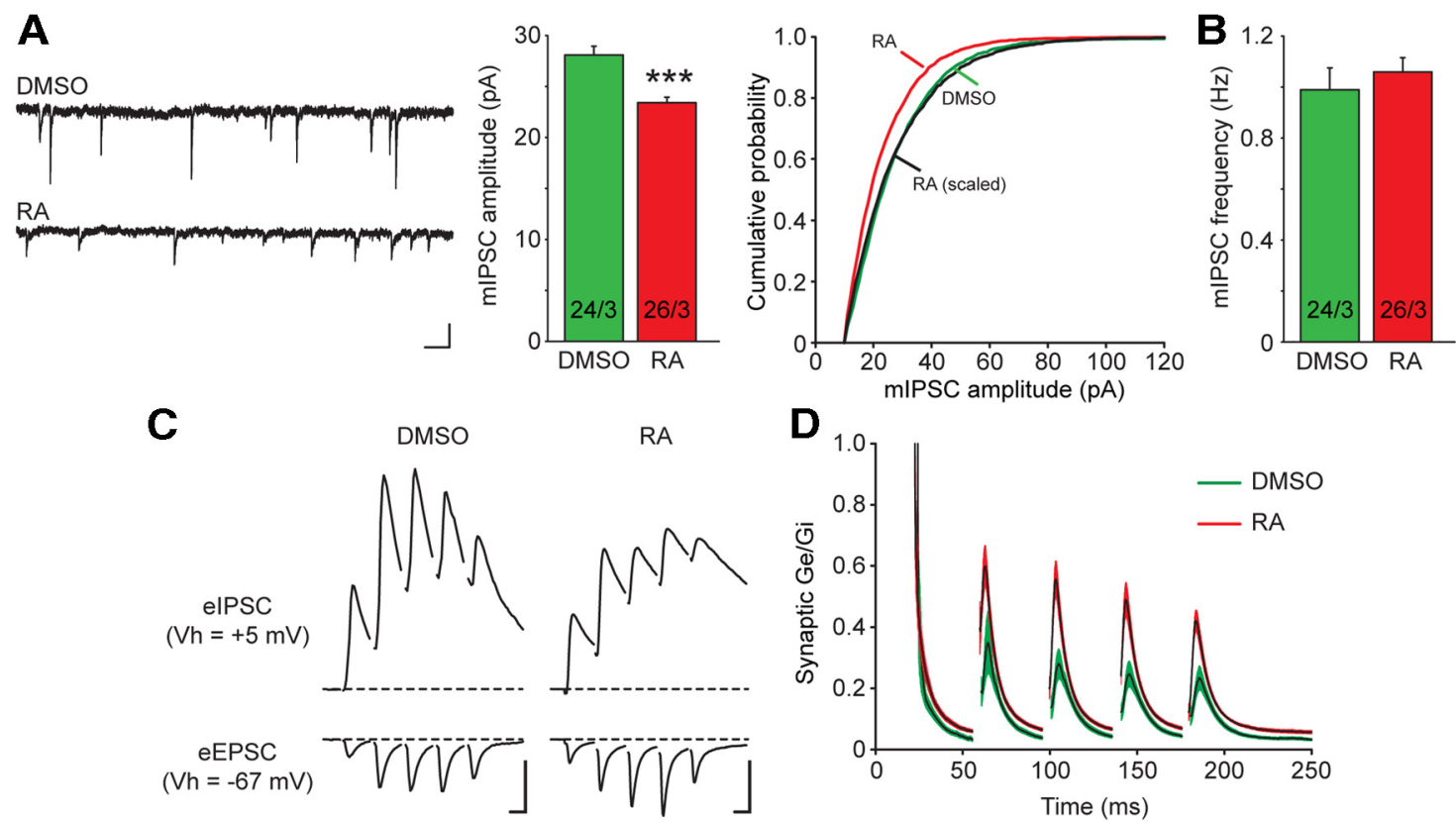

Figure 6. RA induces downscaling of synaptic inhibition and increases excitation/inhibition ratio in acute hippocampal slices. $A$, Representative traces and amplitude analysis of mIPSC recordings obtained from CA1 pyramidal neurons of acute hippocampal slices incubated with DMSO or RA. ${ }^{* * *} p<0.001$. Calibration: 20 pA, 0.5 s. B, Frequency analysis of mIPSCs recorded in $A$. C, Example traces of 25 Hz five-pulse train evoked IPSCS and EPSCs recorded in the same wild-type CA1 pyramidal neurons treated with DMSO or RA. Calibration: 200 pA, 20 ms. D, Synaptic excitatory/inhibitory conductance ratio Ge/Gi (black line indicates mean; red or green shading indicates SEM) of the synaptic responses to train stimulation in wild-type neurons $(n / N=8 / 3)$. The peak of first pulse is cutoff at $1 \mathrm{for}$ display purpose.

mRNAs that are bound to RAR $\alpha$ (Aoto et al., 2008; Poon and Chen, 2008; Sarti et al., 2012). We asked whether the action of RA on inhibitory synaptic transmission uses a similar nongenomic mechanism. The transcription inhibitor actinomycin D had no effect on the RA-induced reduction of mIPSC amplitude (DMSO, $35.89 \pm 3.37 \mathrm{pA}$; RA, $23.01 \pm 1.50 \mathrm{pA}$; RA + actinomycin $\mathrm{D}, 25.19 \pm 2.00 \mathrm{pA} ; p<0.01$ ), whereas inhibitors of protein synthesis completely abolished RA's effect on the mIPSC amplitude (RA + anisomycin, $34.79 \pm 3.04 \mathrm{pA}$; RA + cycloheximide, $35.91 \pm 2.26 \mathrm{pA})($ Fig. 5 A).

The RA receptor RAR $\alpha$ is required for RA's effect on synaptic excitation because both shRNA-mediate knockdown and Crerecombinase-mediated conditional knock $\operatorname{RAR} \alpha$ eliminated RA's action on excitatory synaptic transmission and blocked homeostatic upregulation of synaptic excitation (Aoto et al., 2008; Sarti et al., 2012). To investigate the requirement for RAR $\alpha$ in downscaling of synaptic inhibition, we infected CA1 pyramidal neurons from conditional RAR $\alpha$ KO mice $\left(\mathrm{RAR} \alpha^{\mathrm{fl} / \mathrm{fl}}\right)$ with lentivirus expressing either an active or inactive GFP-tagged Crerecombinase (Cre or $\Delta$ Cre) (Kaeser et al., 2011). We recorded eIPSCs simultaneously from an infected and an uninfected neuron adjacent to each other by stimulating the region of stratum radiatum next to the two neurons (Fig. $5 B$ ). This allows us to directly compare the size of eIPSCs of the infected and the uninfected neurons. Based on our observations above on the mIPSC amplitudes and synaptic $\mathrm{GABA}_{\mathrm{A}} \mathrm{R}$ surface expression (Figs. $1 B$ and Fig. 3), RA is expected to reduce eIPSCs as well. Therefore, neurons with impaired downscaling of synaptic inhibition should exhibit bigger eIPSCs compared with wild-type neurons. Indeed, although knock-out of RAR $\alpha$ did not affect basal inhibitory synaptic transmission (Cre, $89.18 \pm 9.25$ pA; uninfected, $96.64 \pm 9.40 \mathrm{pA}$ ) (Fig. 5C), RA treatment reduced the eIPSC amplitudes in uninfected neurons, rendering them significantly smaller than those from neighboring Cre-recombinase expressing $\operatorname{RAR} \alpha \mathrm{KO}$ neurons (Cre, $112.41 \pm 27.17 \mathrm{pA}$; uninfected,
$58.47 \pm 13.19 \mathrm{pA}$ ) (Fig. $5 C$ ), indicating that the RA-induced downregulation of eIPSC is significantly impaired in $\operatorname{RAR} \alpha \mathrm{KO}$ neurons. This effect is not the result of side effects of viral injection as infection with lentivirus expressing the inactive Cre $(\Delta$ Cre) did not cause such changes (DMSO/ $\Delta$ Cre, $98.5 \pm 11.80$ $\mathrm{pA}$; DMSO/uninfected, $97.70 \pm 9.35 \mathrm{pA} ; \mathrm{RA} / \Delta \mathrm{Cre}, 122.67 \pm$ 14.40 pA; RA/uninfected, $123.62 \pm 11.19 \mathrm{pA}$ ) (Fig. 5D).

Structure-function analysis showed that different domains of RAR $\alpha$ are associated with different functions. Whereas the DNAbinding domain (DBD) mediates its nuclear function (Evans, 1988; Green and Chambon, 1988; Tasset et al., 1990), the $\mathrm{C}$-terminal LBD/F domain is required for the nongenomic action of RAR $\alpha$ through RA and mRNA binding (Poon and Chen, 2008; Sarti et al., 2012). The deletion mutants of RAR $\alpha$ thus provide useful tools to probe the involvement of different functions of RAR $\alpha$ in downscaling of synaptic inhibition when expressed in RAR $\alpha$ KO neurons. Coexpression of $\operatorname{RAR} \alpha$ LBD/F with Cre restored RA-induced homeostatic downregulation of eIPSCs (DMSO/Cre + LBD/F, $116.35 \pm 11.92$ pA; DMSO/uninfected, $117.80 \pm 15.46 \mathrm{pA}$; RA/Cre + LBD/F, $95.04 \pm 9.94 \mathrm{pA}$; RA/ uninfected, $86.72 \pm 8.40 \mathrm{pA}$ ) (Fig. $5 E$ ). By contrast, coexpression of RAR $\alpha$ DBD failed to rescue downscaling of eIPSCs (DMSO/ Cre + DBD, $108.46 \pm 15.14$ pA; DMSO/uninfected, $97.79 \pm$ $10.12 \mathrm{pA}$; RA/Cre + DBD, $130.74 \pm 12.64 \mathrm{pA}$; RA/uninfected, $83.39 \pm 11.65 \mathrm{pA}$ ) (Fig. $5 F$ ). These data indicate that the nuclear function of RA and RAR $\alpha$ is not involved in the action of RA at inhibitory synapses.

\section{RA alters the synaptic excitation/inhibition balance in acute hippocampal slices}

Given the rapid action of RA on synapses, we wondered whether we could reproduce the effect of RA observed in cultured neurons and cultured slices also in acute slices, where local circuits are better preserved than in culture preparations. Incubation of acute hippocampal slices from young mice (P10) with RA ( $2 \mu \mathrm{M})$ induced 
A
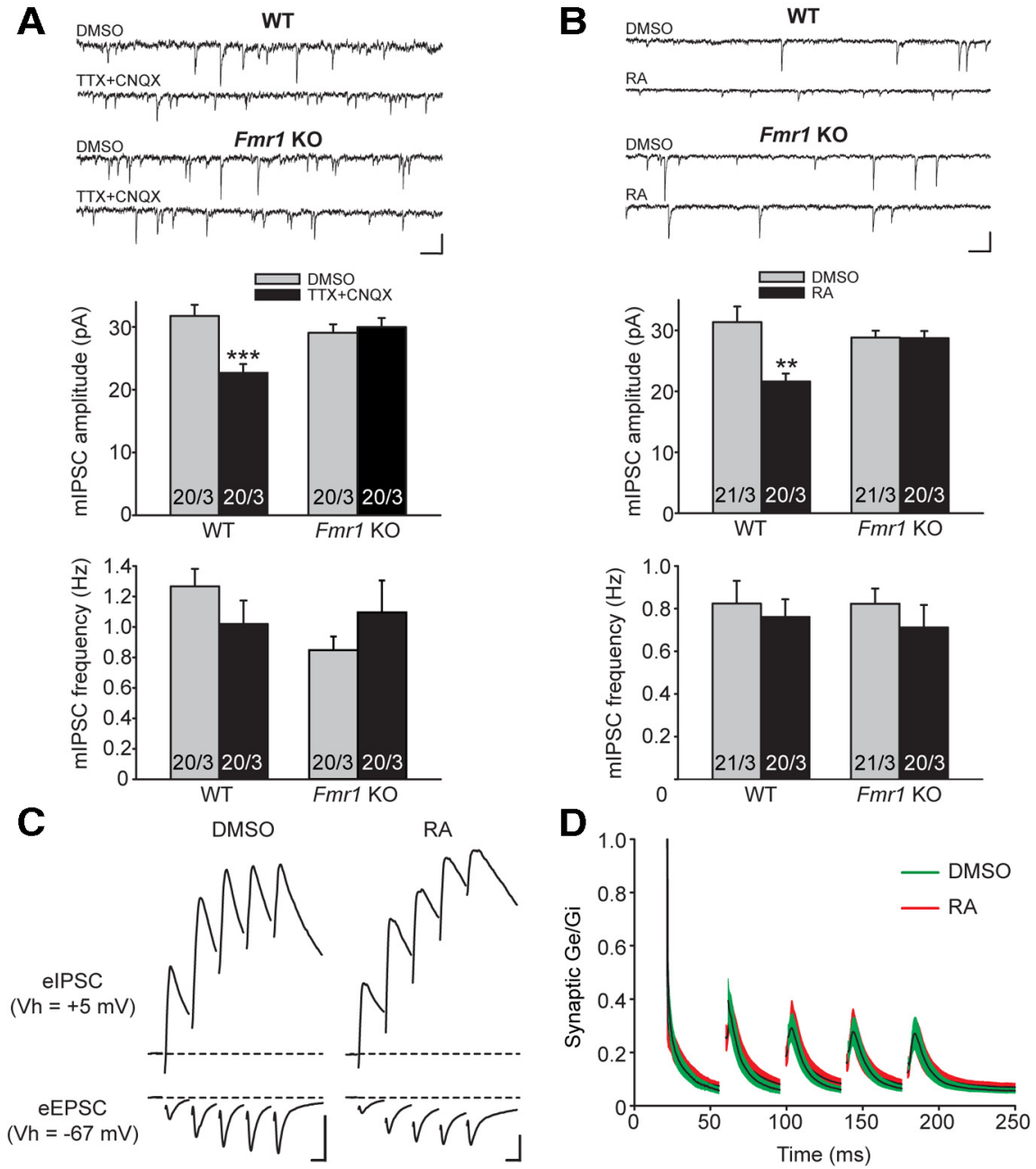

Figure 7. RA-mediated downscaling of synaptic inhibition is absent in Fmr $1 \mathrm{KO}$ neurons. $\boldsymbol{A}$, Representative traces (top) and quantification (bottom) of mIPSCs recorded from WT or Fmr 1 KO CA1 pyramidal neurons in cultured hippocampal slices treated with DMSO or TTX + CNQX. ${ }^{* * *} p<0.001$. B, Representative traces (top) and quantification (bottom) of mIPSCs recorded from WT or Fmr $1 \mathrm{KO}$ CA1 pyramidal neurons in cultured hippocampal slices treated with DMSO or RA. ${ }^{* *} p<0.01$. Calibration: $50 \mathrm{pA}, 0.5 \mathrm{~s}$. C, Example traces of $25 \mathrm{~Hz}$ five-pulse train evoked IPSCS and EPSCs recorded in the same Fmr $1 \mathrm{KO}$ CA1 pyramidal neurons treated with DMSO or RA. Calibration: 200 pA, 20 ms. D, Synaptic excitatory/inhibitory conductance ratio Ge/Gi (mean \pm SEM) of the synaptic responses to train stimulation in $F m r 1$ KO neurons $(n / N=5 / 2)$.

significant downscaling of mIPSCs recorded from CA1 pyramidal neurons (DMSO, $28.08 \pm 0.84 \mathrm{pA}$; RA, $23.40 \pm 0.54 \mathrm{pA}, p<0.001$ ) (Fig. 6A). The mIPSC frequency was not affected (DMSO, $0.99 \pm$ $0.09 \mathrm{~Hz}$; RA, $1.06 \pm 0.06 \mathrm{~Hz}$ ) (Fig. 6B).

Our data suggest that RA, by acting both on synaptic excitation and inhibition, can rapidly and robustly shift the E/I balance of synaptic inputs to a neuron. EPSCs and IPSCs exhibit different rise and decay kinetics. Moreover, inhibitory and excitatory synapses often display different release probabilities and distinct forms of short-term plasticity (depressing vs facilitating synapses) (Zucker, 1989). Therefore, the E/I ratio of a given set of inputs can exhibit rapid dynamics within a pulse (resulting from difference in EPSC and IPSC kinetics) and from pulse to pulse (resulting from difference in short-term plasticity) in a highfrequency burst of action potentials. Given that RA reduces both mIPSCs and eIPSCs, we set out to explore its effect on synaptic E/I balance with evoked responses. We stimulated the stratum radiatum with a 5-pulse $25 \mathrm{~Hz}$ stimulus train and recorded eEPSCs and eIPSCs in the same neurons (Fig. 6C). We found that the synaptic excitatory/inhibitory conductance ratio (Ge/Gi) changed significantly over time (Fig. 6D). For each pulse, because of the more rapid onset and faster rise times of EPSCs than those of IPSCs, the synaptic Ge/Gi ratio was high at the beginning of each response. This was even more evident for the first pulse as $\mathrm{Gi}$ was near zero when $\mathrm{Ge}$ ramped up rapidly. But the $\mathrm{Ge} / \mathrm{Gi}$ ratio decreased rapidly within $10 \mathrm{~ms}$ of stimulus onset as soon as inhibition increased (Fig. 6D). Additionally, the peak Ge/Gi for each pulse exhibited an overall decreasing trend because of the slow decay kinetics of synaptic inhibition (Fig. 6D). RA treatment significantly increased the peak Ge/Gi (Fig. $6 D$, red traces).

\section{Downscaling of inhibitory synaptic transmission is absent in Fmrl KO neurons}

Activity blockade induces RA synthesis in neurons from Fragile- $\mathrm{X}$ model mice (Fmr1 KO), but both synaptic activity blockade- and RA-induced upscaling of excitatory synaptic transmission are absent (Soden and Chen, 2010). These data demonstrated a critical role of FMRP, the protein encoded by fmrl, in synaptic RA signaling and homeostatic synaptic plasticity. We thus asked whether FMRP is specifically required only for homeostatic regulation of excitatory synaptic strength or is universally involved in RA-mediated regulation of both synaptic excitation and synaptic inhibition.

We found that TTX + CNQX treatment produced no reduction in the mIPSC amplitude of neurons in organotypic cultured hippocampal slices from Fmr1 KO mice but caused a robust reduction of the mIPSC amplitude in wild-type slices (WT/DMSO, $31.77 \pm 1.78 \mathrm{pA}$; WT/ TTX + CNQX, $22.68 \pm 1.40 \mathrm{pA} ; \mathrm{KO} /$ DMSO, $29.08 \pm 1.35 \mathrm{pA}$; KO/TTX + CNQX, $29.99 \pm 1.44 \mathrm{pA})$ (Fig. 7A). Moreover, RA significantly decreased the mIPSC amplitude in WT but not Fmr1 KO neurons (WT/DMSO, $31.38 \pm$ $2.56 \mathrm{pA}$; WT/RA, $21.62 \pm 1.30 \mathrm{pA}$; KO/DMSO, $28.86 \pm 1.12 \mathrm{pA}$; KO/RA, $28.72 \pm 1.19 \mathrm{pA}$ ) (Fig. $7 B$ ). The frequency of mIPSCs was not altered by RA in either WT or Fmr1 KO slices (Fig. 7B). Therefore, FMRP is required for homeostatic regulation of both synaptic inhibition and excitation.

We next examined the effect of RA on the synaptic E/I balance in acute slices from the Fmrl KO mice. Although the basal Ge/Gi ratio was similar to that of the wild-type neurons, RA failed to shift the Ge/Gi balance (Fig. 7C,D), confirming our observation in cultured slices that RA-dependent regulation of synaptic strength is missing in the absence of FMRP expression.

\section{RA alters neuronal excitability through modulation of the synaptic E/I balance}

What could be the functional impact of such an RA-dependent shift in synaptic Ge/Gi? Although the synaptic Ge/Gi ratio resides largely well $<1$, the actual synaptic $\mathrm{E} / \mathrm{I}$ balance is the result of the 
interaction between the driving forces of ion fluxes (dictated by the membrane potential and the reversal potentials of EPSCs and IPSCs) and the synaptic conductance. We therefore simulated synaptic EPSC/IPSC ratios in a $25 \mathrm{~Hz} 5$-pulse train in two scenarios that neurons commonly experience, a resting condition $\left(\mathrm{V}_{\mathrm{m}}\right.$ $=-60 \mathrm{mV}$ ) and a partly depolarized condition $\left(\mathrm{V}_{\mathrm{m}}=-50 \mathrm{mV}\right.$, just below the action potential firing threshold), using the $\mathrm{Ge} / \mathrm{Gi}$ ratio calculated from our recordings (Fig. 6C,D). We adopted wellaccepted reversal potentials of EPSCs and IPSCs $\left(\mathrm{E}_{\mathrm{EPSC}}=0 \mathrm{mV}, \mathrm{E}_{\mathrm{IPSC}}=-65 \mathrm{mV}\right)$. At $-60 \mathrm{mV}$, synaptic excitation dominates inhibition at the onset of each stimulus, even in the DMSO-treated condition, because of the vast difference between driving forces ( $60 \mathrm{mV}$ for EPSC and $5 \mathrm{mV}$ for IPSC), and RA treatment significantly exaggerated the dominance of synaptic excitation (Fig. 8A). By contrast, at $\mathrm{V}_{\mathrm{m}}=-50 \mathrm{mV}$, the synaptic excitation was largely shunted by inhibition because of the shift in driving force after the first pulse (Fig. 8B). RA treatment significantly increased the synaptic EPSC/IPSC ratio and restored the dominance by excitation

(Fig. $8 B$ ). Thus, for a neuron in a slightly depolarized state, RA robustly enhances the firing probability induced by a bursting input through reversing the E/I balance. In the Fmr1 KO mouse, because of the deficiency in synaptic RA signaling and homeostatic synaptic plasticity, such modification of the E/I balance is lost (Fig. 8C,D).

\section{Discussion}

In this study, we show that RA mediates homeostatic downscaling of synaptic inhibition and that, similar to RA-dependent upscaling of synaptic excitation, RA-dependent downscaling of synaptic inhibition requires FMRP (Soden and Chen, 2010). Blocking RA synthesis completely prevented the activity blockade-induced downscaling of synaptic inhibition. Direct application of RA rapidly and robustly suppressed synaptic inhibition by triggering the removal of $\mathrm{GABA}_{\mathrm{A}}$ Rs from synapses. The effect of RA on synaptic inhibition was occluded by prolonged synaptic activity blockade. Similar to RA-induced increase in synaptic excitation, the RA-induced decrease in synaptic inhibition required protein synthesis but not gene transcription, and involved a nontranscriptional function of $\operatorname{RAR} \alpha$. However, the upscaling of synaptic excitation and downscaling of synaptic inhibition by RA were not dependent on each other because blocking excitatory upscaling did not affect inhibitory downscaling, suggesting that RA acts as a master organizer of neuronal activity by independently regulating excitatory and inhibitory synapses. In organizing the activity of neurons, RA appears to activate parallel cellular pathways to modulate synaptic excitation and inhibition in a coordinated fashion. The result of such orchestrated modulation in response to reduced synaptic excitation is a rapid increase in the synaptic E/I ratio, which may be responsible for subsequent changes in Hebbian plasticity at the affected synapses (Chen et al., 2013).
$\mathrm{GABA}_{\mathrm{A}}$ Rs mediate most fast synaptic inhibition in the CNS. Modulation of $\mathrm{GABA}_{\mathrm{A}} \mathrm{R}$ trafficking to and out of synapses underlies many neuronal excitability changes under both physiological and pathological conditions (reviewed by Luscher et al., 2011). Endocytosis of $\mathrm{GABA}_{\mathrm{A}}$ Rs occurs primarily through clathrin- and dynamin-dependent mechanisms and requires interactions of $\mathrm{GABA}_{\mathrm{A}} \mathrm{R} \beta$ and $\gamma$ subunits with the clathrin adaptor protein AP2 (McDonald et al., 1998; Brandon et al., 2000, 2002, 2003; Kittler et al., 2000, 2005, 2008; Smith et al., 2008). We found that a dominant-negative dynamin mutant blocked the RA-mediated reduction of synaptic inhibition (although somewhat surprisingly, it did not affect basal inhibitory transmission), suggesting that inhibitory downscaling is mediated by enhanced endocytosis of $\mathrm{GABA}_{\mathrm{A}}$ Rs. Interestingly, the effect of RA on inhibitory synapses also required de novo protein synthesis, suggesting that a newly synthesized protein activates $\mathrm{GABA}_{\mathrm{A}} \mathrm{R}$ endocytosis. No such protein has yet been described; indeed, the very existence of a protein synthesis-dependent endocytosis pathway is novel.

Although RA's action at excitatory and inhibitory synapses both require protein synthesis and expression of FMRP, the end result of the two processes is diametrically opposite: upscaling of synaptic excitation involves new synthesis of AMPARs that are then inserted into synapses, whereas downscaling of synaptic inhibition involves new protein synthesis that causes the removal of $\mathrm{GABA}_{\mathrm{A}} \mathrm{Rs}$. This raises the question of whether our previous view that upscaling of synaptic excitation is simply the result of new AMPAR synthesis may have been too limited, and whether upscaling may also involve new synthesis of a regulatory protein that controls synaptic AMPAR trafficking, in addition to stimulating new AMPAR synthesis itself. Thus, we would like to posit that the protein synthesis-dependent actions of RA may be more regulatory than executive for both upscaling and downscaling, and involve the synthesis of one or several short-lived protein core factors that then promote both AMPAR insertion and GABAR 
endocytosis. This hypothesis provides the simplest explanation for all available data, but alternative, more complicated scenarios, such as multiple independent regulatory and executive pathways, cannot be ruled out.

RA is the first molecule identified that mediates homeostatic heterosynaptic regulation of inhibitory synapses. This role of RA is similar to that of endocannabinoids, BDNF, and nitric oxide in mediating heterosynaptic forms of inhibitory synaptic plasticity (e.g., i-LTD or i-LTP) (reviewed by Castillo et al., 2011). Moreover, endocannabinoids, BDNF, and nitric oxide also act on excitatory synapses, such as RA. Likewise, TNF $\alpha$ has been shown to induce a rapid insertion of AMPA receptors and endocytosis of $\mathrm{GABA}_{\mathrm{A}}$ receptors (Stellwagen et al., 2005). However, RA signaling exhibits one fundamental distinction: i-LTP and i-LTD are induced by activation of excitatory synapses and an increase in dendritic calcium levels, whereas RA-mediated regulation of synaptic inhibition and excitation is triggered by silencing excitatory synapses and a decrease in dendritic calcium levels. Thus, RA acts as a critical component of the feedback loop linking reduced synaptic excitation to shifts in synaptic E/I balance through homeostatic upregulation of excitatory synaptic strength and downregulation of inhibitory synaptic strength.

Throughout the development of sensory systems, the E/I balance is thought to be generally well preserved. Balanced synaptic excitation and inhibition (e.g., feedforward excitation vs feedforward inhibition) are critical for network stability and information processing (Liu et al., 2007; House et al., 2011; Zhang et al., 2011). Failure to maintain a proper E/I balance has been linked to neurological disorders, including epilepsy, schizophrenia, and autism spectrum disorders (Rubenstein and Merzenich, 2003; Lewis et al., 2005; Ramocki and Zoghbi, 2008; Südhof, 2008; Chao et al., 2010). In the mouse model of Fragile-X syndrome (the Fmr1 KO), an imbalance of excitation and inhibition and network hyperexcitability was reported in layer 4 of the barrel cortex (Gibson et al., 2008). Additionally, we observed a complete absence of RA-mediated homeostatic regulation of both synaptic excitation (Soden and Chen, 2010) and inhibition (Fig. 1). Moreover, although the E/I ratio in the hippocampal CA1 region appears to be similar between WT and Fmr1KO neurons (likely through compensation at the circuit level), the ability of $\mathrm{RA}$ to alter the $\mathrm{E} / \mathrm{I}$ ratio in a stimulus-dependent fashion is lost in Fmr1KO neurons (Fig. 7).

As the mechanistic links between E/I imbalance and altered social behavior are just beginning to be uncovered (Yizhar et al., 2011), future investigations are needed to provide molecular, cellular, and circuitry explanations for the behavioral abnormalities in psychiatric diseases. The ability of RA to activate two independent and parallel pathways that mediate concomitant upscaling of synaptic excitation and downscaling of synaptic inhibition allows a greater dynamic range for synaptic homeostasis organized by one single molecule. Thus, RA is a unique synaptic signaling molecule that may play an instructive role in sculpting synaptic inputs based on their activity history to enable efficient encoding, processing, and storing of stimulus-specific information.

\section{References}

Aoto J, Nam CI, Poon MM, Ting P, Chen L (2008) Synaptic signaling by all-trans retinoic acid in homeostatic synaptic plasticity. Neuron 60:308320. CrossRef Medline

Brandon NJ, Delmas P, Kittler JT, McDonald BJ, Sieghart W, Brown DA, Smart TG, Moss SJ (2000) GABAA receptor phosphorylation and functional modulation in cortical neurons by a protein kinase $\mathrm{C}$-dependent pathway. J Biol Chem 275:38856-38862. CrossRef Medline

Brandon NJ, Jovanovic JN, Colledge M, Kittler JT, Brandon JM, Scott JD,
Moss SJ (2003) A-kinase anchoring protein 79/150 facilitates the phosphorylation of GABA(A) receptors by cAMP-dependent protein kinase via selective interaction with receptor beta subunits. Mol Cell Neurosci 22:87-97. CrossRef Medline

Brandon N, Jovanovic J, Moss S (2002) Multiple roles of protein kinases in the modulation of gamma-aminobutyric acid(A) receptor function and cell surface expression. Pharmacol Ther 94:113-122. CrossRef Medline

Castillo PE, Chiu CQ, Carroll RC (2011) Long-term plasticity at inhibitory synapses. Curr Opin Neurobiol 21:328-338. CrossRef Medline

Chao HT, Chen H, Samaco RC, Xue M, Chahrour M, Yoo J, Neul JL, Gong S, Lu HC, Heintz N, Ekker M, Rubenstein JL, Noebels JL, Rosenmund C, Zoghbi HY (2010) Dysfunction in GABA signalling mediates autismlike stereotypies and Rett syndrome phenotypes. Nature 468:263-269. CrossRef Medline

Chapellier B, Mark M, Garnier JM, LeMeur M, Chambon P, Ghyselinck NB (2002) A conditional floxed (loxP-flanked) allele for the retinoic acid receptor alpha (RARalpha) gene. Genesis 32:87-90.

Chen L, Lau AG, Sarti F (2013) Synaptic retinoic acid signaling and homeostatic synaptic plasticity. Neuropharmacology Advance online publication. Retrieved Dec. 25, 2012. doi: 10.1016/j.neuropharm.2012.12.004. CrossRef Medline

Chu P, Murray S, Lissin D, von Zastrow M (1997) Delta and kappa opioid receptors are differentially regulated by dynamin-dependent endocytosis when activated by the same alkaloid agonist. J Biol Chem 272:27124-27130. CrossRef Medline

Evans RM (1988) The steroid and thyroid hormone receptor superfamily. Science 240:889-895. CrossRef Medline

Fagiolini M, Fritschy JM, Löw K, Möhler H, Rudolph U, Hensch TK (2004) Specific GABAA circuits for visual cortical plasticity. Science 303:16811683. CrossRef Medline

Gibson JR, Bartley AF, Hays SA, Huber KM (2008) Imbalance of neocortical excitation and inhibition and altered UP states reflect network hyperexcitability in the mouse model of fragile X syndrome. J Neurophysiol 100: 2615-2626. CrossRef Medline

Green S, Chambon P (1988) Nuclear receptors enhance our understanding of transcription regulation. Trends Genet 4:309-314. CrossRef Medline

Haas K, Li J, Cline HT (2006) AMPA receptors regulate experiencedependent dendritic arbor growth in vivo. Proc Natl Acad Sci U S A 103: 12127-12131. CrossRef Medline

Haider B, Duque A, Hasenstaub AR, McCormick DA (2006) Neocortical network activity in vivo is generated through a dynamic balance of excitation and inhibition. J Neurosci 26:4535-4545. CrossRef Medline

Hensch TK, Fagiolini M (2005) Excitatory-inhibitory balance and critical period plasticity in developing visual cortex. Prog Brain Res 147:115-124. CrossRef Medline

Hensch TK, Fagiolini M, Mataga N, Stryker MP, Baekkeskov S, Kash SF (1998) Local GABA circuit control of experience-dependent plasticity in developing visual cortex. Science 282:1504-1508. CrossRef Medline

Herring D, Huang R, Singh M, Robinson LC, Dillon GH, Leidenheimer NJ (2003) Constitutive GABAA receptor endocytosis is dynamin-mediated and dependent on a dileucine AP2 adaptin-binding motif within the beta 2 subunit of the receptor. J Biol Chem 278:24046-24052. CrossRef Medline

Higley MJ, Contreras D (2006) Balanced excitation and inhibition determine spike timing during frequency adaptation. J Neurosci 26:448-457. CrossRef Medline

House DR, Elstrott J, Koh E, Chung J, Feldman DE (2011) Parallel regulation of feedforward inhibition and excitation during whisker map plasticity. Neuron 72:819-831. CrossRef Medline

Jakawich SK, Nasser HB, Strong MJ, McCartney AJ, Perez AS, Rakesh N, Carruthers CJ, Sutton MA (2010) Local presynaptic activity gates homeostatic changes in presynaptic function driven by dendritic BDNF synthesis. Neuron 68:1143-1158.

Kaeser PS, Deng L, Wang Y, Dulubova I, Liu X, Rizo J, Südhof TC (2011) RIM proteins tether $\mathrm{Ca}^{2+}$ channels to presynaptic active zones via a direct PDZ-domain interaction. Cell 144:282-295. CrossRef Medline

Kilman V, van Rossum MC, Turrigiano GG (2002) Activity deprivation reduces miniature IPSC amplitude by decreasing the number of postsynaptic $\mathrm{GABA}(\mathrm{A})$ receptors clustered at neocortical synapses. J Neurosci 22 : 1328-1337. Medline

Kittler JT, Delmas P, Jovanovic JN, Brown DA, Smart TG, Moss SJ (2000) Constitutive endocytosis of $\mathrm{GABA}_{\mathrm{A}}$ receptors by an association with the 
adaptin AP2 complex modulates inhibitory synaptic currents in hippocampal neurons. J Neurosci 20:7972-7977. Medline

Kittler JT, Thomas P, Tretter V, Bogdanov YD, Haucke V, Smart TG, Moss SJ (2004) Huntingtin-associated protein 1 regulates inhibitory synaptic transmission by modulating gamma-aminobutyric acid type A receptor membrane trafficking. Proc Natl Acad Sci U S A 101:12736-12741. CrossRef Medline

Kittler JT, Chen G, Honing S, Bogdanov Y, McAinsh K, Arancibia-Carcamo IL, Jovanovic JN, Pangalos MN, Haucke V, Yan Z, Moss SJ (2005) Phospho-dependent binding of the clathrin AP2 adaptor complex to GABAA receptors regulates the efficacy of inhibitory synaptic transmission. Proc Natl Acad Sci U S A 102:14871-14876. CrossRef Medline

Kittler JT, Chen G, Kukhtina V, Vahedi-Faridi A, Gu Z, Tretter V, Smith KR, McAinsh K, Arancibia-Carcamo IL, Saenger W, Haucke V, Yan Z, Moss SJ (2008) Regulation of synaptic inhibition by phospho-dependent binding of the AP2 complex to a YECL motif in the GABAA receptor gamma2 subunit. Proc Natl Acad Sci U S A 105:3616-3621. CrossRef Medline

Komatsu Y (1994) Age-dependent long-term potentiation of inhibitory synaptic transmission in rat visual cortex. J Neurosci 14:6488-6499. Medline

Kotak VC, Fujisawa S, Lee FA, Karthikeyan O, Aoki C, Sanes DH (2005) Hearing loss raises excitability in the auditory cortex. J Neurosci 25:39083918. CrossRef Medline

Levy RB, Reyes AD (2011) Coexistence of lateral and co-tuned inhibitory configurations in cortical networks. PLoS Comput Biol 7:e1002161. CrossRef Medline

Lewis DA, Hashimoto T, Volk DW (2005) Cortical inhibitory neurons and schizophrenia. Nat Rev Neurosci 6:312-324. CrossRef Medline

Liu Y, Zhang LI, Tao HW (2007) Heterosynaptic scaling of developing GABAergic synapses: dependence on glutamatergic input and developmental stage. J Neurosci 27:5301-5312. CrossRef Medline

Luscher B, Fuchs T, Kilpatrick CL (2011) $\mathrm{GABA}_{\mathrm{A}}$ receptor traffickingmediated plasticity of inhibitory synapses. Neuron 70:385-409. CrossRef Medline

Maffei A, Nelson SB, Turrigiano GG (2004) Selective reconfiguration of layer 4 visual cortical circuitry by visual deprivation. Nat Neurosci 7:1353-1359. CrossRef Medline

McDonald BJ, Amato A, Connolly CN, Benke D, Moss SJ, Smart TG (1998) Adjacent phosphorylation sites on $\mathrm{GABA}_{\mathrm{A}}$ receptor beta subunits determine regulation by cAMP-dependent protein kinase. Nat Neurosci 1:2328. CrossRef Medline

Morales B, Choi SY, Kirkwood A (2002) Dark rearing alters the development of GABAergic transmission in visual cortex. J Neurosci 22:80848090. Medline

Poon MM, Chen L (2008) Retinoic acid-gated sequence-specific translational control by RARalpha. Proc Natl Acad Sci U S A 105:20303-20308. CrossRef Medline

Ramocki MB, Zoghbi HY (2008) Failure of neuronal homeostasis results in common neuropsychiatric phenotypes. Nature 455:912-918. CrossRef Medline

Rubenstein JL, Merzenich MM (2003) Model of autism: increased ratio of excitation/inhibition in key neural systems. Genes Brain Behav 2:255-267. CrossRef Medline

Russo JE, Hauguitz D, Hilton J (1988) Inhibition of mouse cytosolic aldehyde dehydrogenase by 4-(diethylamino)benzaldehyde. Biochem Pharmacol 37:1639-1642. CrossRef Medline

Saliba RS, Michels G, Jacob TC, Pangalos MN, Moss SJ (2007) Activitydependent ubiquitination of GABA(A) receptors regulates their accumulation at synaptic sites. J Neurosci 27:13341-13351. CrossRef Medline
Saliba RS, Gu Z, Yan Z, Moss SJ (2009) Blocking L-type voltage-gated $\mathrm{Ca}^{2+}$ channels with dihydropyridines reduces gamma-aminobutyric acid type A receptor expression and synaptic inhibition. J Biol Chem 284:32544-32550. CrossRef Medline

Sarti F, Schroeder J, Aoto J, Chen L (2012) Conditional RARalpha knockout mice reveal acute requirement for retinoic acid and RARalpha in homeostatic plasticity. Front Mol Neurosci 5:16. CrossRef Medline

Shi S, Hayashi Y, Esteban JA, Malinow R (2001) Subunit-specific rules governing AMPA receptor trafficking to synapses in hippocampal pyramidal neurons. Cell 105:331-343. CrossRef Medline

Sibilla S, Ballerini L (2009) GABAergic and glycinergic interneuron expression during spinal cord development: dynamic interplay between inhibition and excitation in the control of ventral network outputs. Prog Neurobiol 89:46-60. CrossRef Medline

Smith KR, McAinsh K, Chen G, Arancibia-Carcamo IL, Haucke V, Yan Z, Moss SJ, Kittler JT (2008) Regulation of inhibitory synaptic transmission by a conserved atypical interaction of GABA(A) receptor beta- and gamma-subunits with the clathrin AP2 adaptor. Neuropharmacology 55 : 844-850. CrossRef Medline

Soden ME, Chen L (2010) Fragile X protein FMRP is required for homeostatic plasticity and regulation of synaptic strength by retinoic acid. J Neurosci 30:16910-16921. CrossRef Medline

Stellwagen D, Beattie EC, Seo JY, Malenka RC (2005) Differential regulation of AMPA receptor and GABA receptor trafficking by tumor necrosis factor-alpha. J Neurosci 25:3219-3228. CrossRef Medline

Südhof TC (2008) Neuroligins and neurexins link synaptic function to cognitive disease. Nature 455:903-911. CrossRef Medline

Sun YJ, Wu GK, Liu BH, Li P, Zhou M, Xiao Z, Tao HW, Zhang LI (2010) Fine-tuning of pre-balanced excitation and inhibition during auditory cortical development. Nature 465:927-931. CrossRef Medline

Tasset D, Tora L, Fromental C, Scheer E, Chambon P (1990) Distinct classes of transcriptional activating domains function by different mechanisms. Cell 62:1177-1187. CrossRef Medline

Tracy TE, Yan JJ, Chen L (2011) Acute knockdown of AMPA receptors reveals a trans-synaptic signal for presynaptic maturation. EMBO J 30: 1577-1592. CrossRef Medline

Turrigiano G (2012) Homeostatic synaptic plasticity: local and global mechanisms for stabilizing neuronal function. Cold Spring Harb Perspect Biol 4:a005736. CrossRef Medline

Wang HL, Zhang Z, Hintze M, Chen L (2011) Decrease in calcium concentration triggers neuronal retinoic acid synthesis during homeostatic synaptic plasticity. J Neurosci 31:17764-17771. CrossRef Medline

Yang S, Weiner BD, Zhang LS, Cho SJ, Bao S (2011) Homeostatic plasticity drives tinnitus perception in an animal model. Proc Natl Acad Sci U S A 108:14974-14979. CrossRef Medline

Yizhar O, Fenno LE, Prigge M, Schneider F, Davidson TJ, O’Shea DJ, Sohal VS, Goshen I, Finkelstein J, Paz JT, Stehfest K, Fudim R, Ramakrishnan C, Huguenard JR, Hegemann P, Deisseroth K (2011) Neocortical excitation/inhibition balance in information processing and social dysfunction. Nature 477:171-178. CrossRef Medline

Yu LM, Goda Y (2009) Dendritic signalling and homeostatic adaptation. Curr Opin Neurobiol 19:327-335. CrossRef Medline

Zhang Z, Jiao YY, Sun QQ (2011) Developmental maturation of excitation and inhibition balance in principal neurons across four layers of somatosensory cortex. Neuroscience 174:10-25. CrossRef Medline

Zucker RS (1989) Short-term synaptic plasticity. Annu Rev Neurosci 12: 13-31. CrossRef Medline 